\title{
De vuelta con la historia en tiempo presente. Imágenes artísticas y poder en la representación de los conflictos bélicos contemporáneos
}

\section{Back with History in Present Time. Artistic Pictures and Power in the Representation of the Contemporary Wars}

Artículo recibido el 3I de julio de 20I8; devuelto para revisión el 29 de marzo de 20I9; aceptado el 23 de julio de 2019 .

Rut Martín Hernández Departamento de Pintura y Conservación-Restauración, Facultad de Bellas Artes, Universidad Complutense de Madrid. rutmartin@pdi. ucm.es, http://orcid.org/oooo-0002-3304-9IX

Líneas de investigación Estética; imágenes artísticas y agencia icónica.

Lines of research Aesthetic, artistic images; inconic agency.

Publicación más relevante

"Within the Limits of the Body. Artistic Imagen of HIV/AIDs in Spain and its Relationship with the Cultural Industry", en G. Subero ed., HIV in World Cultures. Three Decades of Representations (Nueva York: Routledge, 2013).

Resumen En las últimas décadas, las prácticas artísticas contemporáneas se han aproximado a la representación de los conflictos bélicos desde una perspectiva que supone un punto de inflexión y permite realizar una investigación cuyo objetivo se centra en analizar el poder de la imagen en la conformación de imaginarios colectivos, así como su capacidad de agencia para procesos de emancipación que surgen a partir de y desde dichas imágenes artísticas. Por otra parte, este objetivo sirve como punto de partida para abordar las tensiones y la visibilización de las estructuras de poder en las guerras geoeconómicas. Esta aportación presenta los principales ejes conceptuales que parten del análisis de una serie de obras artísticas contemporáneas relacionadas con el objeto de estudio y que ponen de manifiesto las preocupaciones, los logros y los conflictos de las prácticas artísticas contemporáneas que abordan estos temas.

Palabras clave Guerra; imagen; agencia, prácticas artísticas; sociedad en red; historia; medios de comunicación.

Abstract In recent decades, contemporary practices in art have approached the representation of wars from a point of view which is a turning point and allows us to carry out a targeted research focusing on the power 
of the image in the formation of collective imaginaries, as well as its capacity for agency and the emancipation processes that arise from such artistic images. On the other hand, this aim serves as a starting point for confronting the tensions and making visible the structures of power in geo-economic wars. This paper presents the main conceptual axes brought to light by the analysis of current artistic works related with the object of study, and manifests the concerns, achievements and conflicts of contemporary artistic practices that address these issues.

Keywords War; picture; agency; artistic practices; network society; history; mass media. 
DOI: http://dx.doi.org/10.22201/iie.18703062e.2019.115.2695

\author{
RUT MARTÍN HERNÁNDEZ \\ UNIVERSIDAD COMPLUTENSE DE MADRID
}

\title{
De vuelta con la historia en tiempo presente Imágenes artísticas y poder en la representación de los conflictos bélicos contemporáneos
}

$\mathrm{E}$ 1 papel de la imagen es clave en la conformación de imaginarios en torno a conflictos bélicos. A lo largo de la historia han sido, en primer lugar, la pintura y, posteriormente, la fotografía, las técnicas privilegiadas mediante las cuales la historia ha devenido en imagen. Una imagen con una capacidad de afectación privilegiada y con un poder esencial en la conformación de espacios políticos y posicionamientos ideológicos. Un poder que ha actuado desde una segunda posición a la cual ha sido relegada la imagen, que habitualmente ha actuado para ilustrar, documentar o legitimar los hechos acontecidos y ha sido, por otra parte, un elemento clave dentro de las políticas de carácter propagandístico. Es precisamente, desde las prácticas artísticas, donde la imagen emerge al primer plano y se posiciona como lo que en realidad muchas veces ha sido, un espacio discursivo clave que funciona también a otros niveles, afectando los cuerpos y construyendo otros posibles espacios de sentido.

En este aspecto cabría cuestionarse ¿pueden las imágenes artísticas ofrecer otros posibles acercamientos a los conflictos bélicos? ¿Qué pueden aportar a los discursos icónicos de los medios de comunicación y de las redes sociales? ¿Presentan conexiones y relaciones entre ellas y en relación con los discursos artísticos contemporáneos? ¿Cuáles son las principales estrategias a partir de las cuales se configuran? ¿Logran visibilizar las redes de poder que vertebran 


\section{66 RUT MARTÍN HERNÁNDEZ}

los conflictos bélicos actualmente? ¿Puede valorarse su capacidad de emancipación? Podría establecerse que la hipótesis de partida de esta investigación es que las prácticas artísticas contemporáneas que reflexionan sobre los conflictos bélicos son capaces de construir imaginarios alternativos, afectando al espectador para tomar una posición crítica susceptible de generar espacio político y permitir la configuración de unos relatos históricos de manera diferencial a los que producen los medios de comunicación y las redes sociales.

Los conflictos bélicos contemporáneos han sido conscientes de ese poder que emana de la imagen y, en consecuencia, las imágenes de los mismos han sido fundamentales no únicamente en la conformación del relato, sino que han llegado a transformar, en algunas ocasiones, el propio conflicto. En este sentido, resulta clave comprender cómo las estrategias que se plantean desde las prácticas artísticas suponen un campo discursivo de reflexión sobre los propios conflictos y, a su vez, sobre las posibilidades de emancipación de este tipo de imágenes en la conformación de unos imaginarios otros.

Las guerras contemporáneas han cambiado en sus argumentos, su estructura, sus objetivos, sus motivaciones y sus alianzas. Ulrich Oslender ${ }^{\mathrm{I}}$ plantea que los conflictos actualmente están estructurados con base en las lógicas geoeconómicas, cuyas estructuras desbordan los discursos políticos y los territorios de Estado-nación. Por otra parte, esto ha influido de manera significativa en la visibilidad. Las nuevas tecnologías no sólo han supuesto avances significativos en cuestión de armamento, estructuras de mando o tácticas y estrategias, sino que han condicionado de forma esencial, junto con los medios de comunicación, la representación de la guerra.

Susan Sontag ${ }^{2}$ explica cómo durante la guerra de los Balcanes las mismas imágenes de niños muertos se distribuyeron tanto entre serbios como entre croatas con objetivos propagandísticos. El control de la difusión de las imágenes de guerra se define en la actualidad por una nueva censura que, en realidad, se ha ido gestando desde entonces. Los medios que cubrieron el conflicto en la guerra del Golfo fueron estrictamente controlados, al igual que los que transmitieron la primera guerra de Irak. Tras los atentados del in de septiembre de 200 i se ha vuelto evidente el control de los gobiernos en la circulación

I. Ulrich Oslender, "Construyendo contrapoderes a las nuevas guerras geo-económicas: caminos hacia una globalización de la resistencia", Revista Tabula Rasa, núm. 2 (2004): 67.

2. Susan Sontag, "Looking at War. Photography's View of Devastation and Death", The New Yorker, 9 de diciembre de 2002. 
de imágenes e información ya sea vía los medios de difusión de masas, como de Internet y de los medios electrónicos en general. La instauración de unas imágenes que siguen el esquema y las narraciones marcadas por los gobiernos están en consonancia con la representación del poder y ponen de manifiesto la hegemonía de la primera superpotencia mundial, Estados Unidos.

Georges Didi-Huberman expone que "las imágenes de violencia y de barbarie organizadas son actualmente legión. La información televisiva manipula a su antojo las dos técnicas de la minucia y de la demasía". ${ }^{3}$ Las imágenes de torturas de gran dureza evidencian el lado oculto de esas imágenes mediáticas controladas por el poder, como las relativas a las torturas de Abu Ghraib, por poner un ejemplo de las múltiples existentes, retransmitidas internacionalmente y difundidas por medio de Internet $y \tan$ diferentes, por otra parte, a las divulgadas por el gobierno de Estados Unidos de la muerte de Osama Bin Laden. La afluencia de imágenes de este tipo que percibimos habitualmente ha ido en aumento, estamos acostumbrados a convivir con el dolor ajeno mientras realizamos las tareas más cotidianas y acaban siendo parte de nuestras rutinas, en las que quedan anuladas bajo la redundancia y la repetición.

Una de las consecuencias directas de la guerra contra el terror es una voluntad creciente por controlar a la sociedad civil. "En el mapa del nuevo estado de cosas, las personas hemos pasado de ser ciudadanos a sospechosos". ${ }^{4}$ Con la excusa de la seguridad, y una propagación del miedo, ${ }^{5}$ miles de cámaras controlan la vida diaria de miles de ciudadanos como si de un sistema panóptico se tratara; generan miles de imágenes en las que la privacidad e intimidad del individuo se ve vulnerada de forma constante. Las tecnologías están puestas al servicio de una mirada que es a la vez unilateral y múltiple, una mirada que es poder. Los individuos somos así categorizados, jerarquizados, clasificados con base en unas normas disciplinarias que definen modos de conducta homogeneizadores.

Las obras artísticas que tratan este tema han dejado esa pose triunfalista propia del género de la pintura de historia tradicional y ahondan en la necesidad de releer las imágenes que nos llegan de forma redundante a través de los medios

3. Georges Didi-Huberman, Arde la imagen (México: Serieve, 20I2), 3 I.

4. Xavier Ballaz y Marc Folch, "Virtualización y actuaciones del estado-guerra", Athenea Digital, núm. 7 (2005): 9. www.raco.cat/index.php/Athenea/article/viewFile/34184/34023, consultado el 30 de julio, 2018.

5. Para profundizar en esta cuestión se aconseja la consulta de: Paul Virilio, L'Administration de la peur (París: Terxuel, 2010). 
de comunicación, de las redes sociales y otros medios de información alternativos. Se podría considerar que, tal y como plantea Hito Steyerl, "la producción de arte presenta una imagen especular de las formas posdemocráticas del hipercapitalismo que parecen dispuestas a convertirse en el paradigma político dominante de la Posguerra Fría". ${ }^{6}$ Son, por otra parte, imágenes críticas que cuestionan el discurso oficial y el modo en que éste utiliza la imagen, una crítica que también se extiende a la censura y al control que el poder impone sobre dichas representaciones. Existe una voluntad de mostrar la complejidad de lo bélico en un mundo caracterizado por una lógica geoeconómica y de denunciar los abusos y las atrocidades que siguen acompañando a esas batallas, ahora invisibles. Estas obras muestran una realidad poliédrica que cuestiona la verdad o la ficción que se oculta tras toda representación, y que inciden también en el actual control impuesto a la sociedad con la excusa de la lucha contra el terror. ${ }^{7}$

Ante esta situación existen otras posiciones a partir de las cuales, los artistas han articulado sus discursos que se sirven de la extrañeza o el humor para desvelar los mecanismos de poder de estos conflictos. Otra cuestión clave ha sido la renegociación con la historia y la fragmentación de la mirada al pasado, por medio de la reivindicación de las posiciones individuales y subjetivas, en las que la historia se entiende en plural y se conforma como un espacio flexible, dinámico y resignificado desde el presente. Por otra parte, se entiende que en los albores del siglo XXI, las protestas multitudinarias de alcance global han conformado otro espacio de reflexión para los artistas contemporáneos, encontrando en ellas el germen de la transformación social y la posibilidad de representar los estados de malestar de una sociedad que va perdiendo derechos y bienestar en favor de un sistema ante el cual no se siente representada.

Parodias, ironias y escenificaciones. Cuestionando las imágenes del horror

Ante la influencia de los medios de comunicación, Internet y las redes sociales en la representación de lo bélico, muchos artistas encuentran en la parodia y la ironía una estrategia para poner de manifiesto las contradicciones que se generan y los mecanismos ocultos del poder que toman forma en dichas imá-

6. Hito Steyerl, Los condenados de la pantalla (Buenos Aires: Caja Negra), 98.

7. Sobre la investigación específica de esta cuestión véase: Rut Martín Hernández, "Imágenes de lo bélico en el arte contemporáneo", Eikasia, núm. 50 (2013): 3II-322. 
genes. "Estas prácticas transformacionales extienden su ámbito de actuación sobre procesos generativos de la obra de arte en aquel aspecto fundamental de la cita, en el contrato entre espectador y autor, al declarar este último la fuente que toma como punto de partida". ${ }^{8}$

Una de las estrategias clave en este tipo de acercamiento es la apropiación de imágenes ya conocidas que forman parte de los imaginarios colectivos. Como puede observarse en History Stripped Bare (2000), ${ }^{9}$ de Gabriele di Matteo, el artista se apropia de imágenes, de situaciones históricas que han pasado a formar parte de dichos imaginarios y que son extraídas de medios como la fotografía, el cine, la pintura y los medios de comunicación. Los personajes representados, grandes líderes mundiales de todos los tiempos, están desnudos reproduciendo una imagen mil veces vista, lo que genera una situación absurda en la que los grandes acontecimientos de la historia quedan cuestionados, ridicularizados, dejando intuir el velo de impostura de dichas imágenes que han adquirido un significado simbólico. En este sentido, es clave la resignificación de dichas imágenes mediante la inserción de elementos paródicos que funcionan como detonantes para quebrar el significado de las mismas y forzar el análisis crítico por medio de la fisura que establece el humor como elemento desarticulador. Esta cuestión puede corroborarse asimismo en la obra de Alexis Esquivel que crea pequeñas ficciones a partir de imágenes reconocibles procedentes de la cultura de masas e iconos de la cultura occidental, de un imaginario simbólico que proviene tanto de imágenes mediáticas como cinematográficas. En La Paix de Cuito Cuanavale (201I), ${ }^{\mathrm{IO}}$ parte de una referencia directa a la película Invictus (2009) y crea una escena en la que aparecen varios personajes históricos como Nelson Mandela, junto con el jefe rebelde de la UniTA, Jonas Savimbi. Con cierta ironía plantea, en este espacio de entramado de elementos descontextualizados, las complejidades de las sociedades poscoloniales.

8. Alberto Gálvez Giménez, Cita de la pintura. Estrategias autorreferenciales en pintura (Valencia: Institució Alfons el Magnánim-Diputación de Valencia-Colecció Formes Plástiques, 2004), 7I.

9. Esta serie de obras está formada por Ioo pinturas de pequeño fomato realizadas al óleo. Fue expuesta en el Centro Australinao de Arte Contemporáneo (Melbourne, Australia) y puede consultarse en la siguiente url: https://acca.melbourne/exhibition/gabrielle-di-matteo-historystripped-bare/, consultado el 25 de junio de 2019 .

IO. Esta obra está realizada en acrílico sobre tela y tiene unas dimesiones de II $4 \times 175 \mathrm{~cm}$. Para mayor información sobre la misma véase: www.alexisesquivel.com/index.php/seleccion-previa-deobras/, consultado el 25 de junio de 20I9. Un acercamiento a su producción se presenta, asimismo, en el texto publicado en la revista Cuban Studies: Suset Sánchez, "Alexis Esquivel: Entrevista", Cuban Studies, núm. 48 (2019): 340-355. Project MUSE, DOI:IO.1353/cub.2019.0052. 


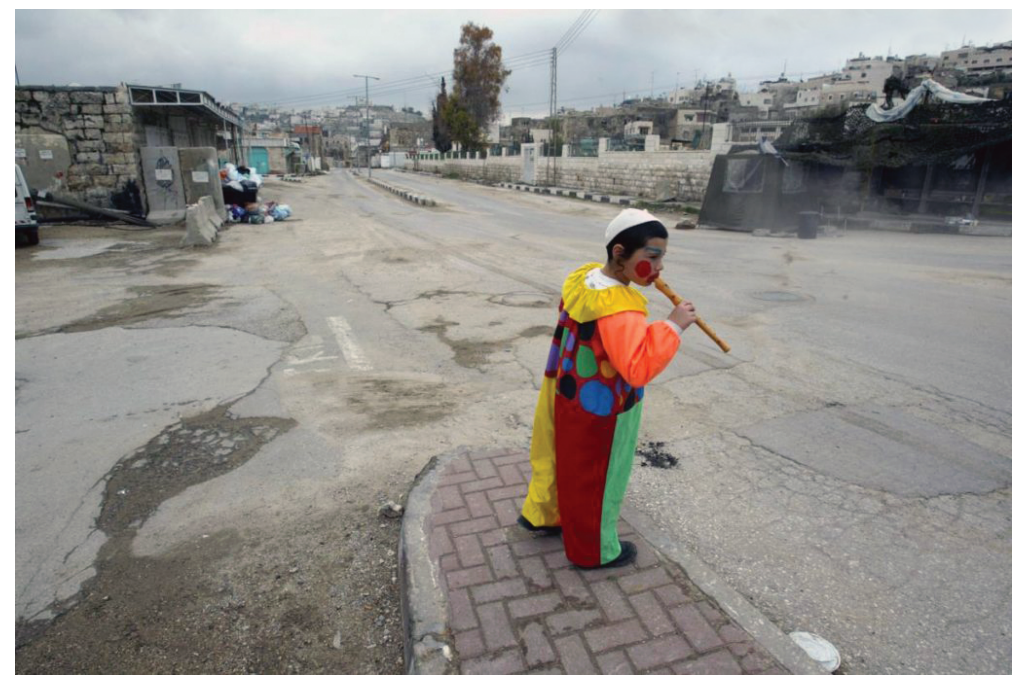

I. Larry Fink, Homenaje a George Grosz, fotografía, 20or. Tomada de: http://www. artnet.com/Magazine/reviews/walrobinson/robinson7-20-3.asp

Estas cuestiones tienen que ver, también, con otra característica común a este tipo de acercamientos que consiste en la inserción de elementos no previstos que implican otras lógicas de lectura no predichas. A lo largo de las décadas hemos aprendido a significar las imágenes con relación a unos modos de relatar acontecimientos de forma lineal y cronológica, en la que las mismas jugaban un papel ilustrador. Introducir unos elementos icónicos otros significa, de igual manera, romper con la linealidad y las lógicas establecidas de las formas de relatar y comprender los acontecimientos. De forma diferencial con lo anteriormente expuesto, Pavel Wolberg, ${ }^{\text {II }}$ artista residente en Tel Aviv, se mueve dentro de los términos del fotoperiodismo, sin embargo, en sus fotografías se pueden apreciar las paradojas de la vida cotidiana en un lugar de conflicto bélico permanente (fig. I). En este caso, la estrategia no es la inserción de lo paródico como punto de quiebre de los imaginarios colectivos, sino la inserción de lo cotidiano. El juego entre los grandes acontecimientos mediante los

II. La obra del autor ha sido contemplada en las siguientes monografías que pueden sevir para ampliar la información al respecto: R. Segal, D. Tartakover, E. Weizman, eds., A Civilian Occupation: The Politics of Israeli Arquitecture (Nueva York: Verso, 2003) y Regev Nathansohn y Dennis Zuev, eds., Sociology of the Visual Sphere (Nueva York: Routledge, 2013). 
cuales suele representarse la historia se cuestiona. Las pequeñas acciones cotidianas representadas ponen de manifiesto otros modos de comprender los conflictos, en los que la vida y la guerra se imbrican hasta acercarnos a una relación por medio de la cual entender las tensiones y los efectos sociales que provoca la violencia en estos lugares. Imágenes que presentan la cruda realidad que se vive en Israel y Palestina confrontando elementos propios de lo bélico con otros que generan un fuerte contraste, como unos niños disfrazados o unos jóvenes travestidos como bailarinas de ballet. ${ }^{\mathrm{I2}} \mathrm{El}$ resultado son imágenes que parecen paródicas, pero que en realidad están analizando, con crudeza, la necesidad de mantener los aspectos más intrascendentes de la vida diaria a pesar de las duras condiciones que generan las guerras, para poder seguir viviendo.

Otra de las estrategias más significativas es la escenificación como recurso para poner en evidencia los mecanismos de poder que rigen el mundo. La parodia y el uso de referencias a determinados artistas históricos sirven para construir unas imágenes artísticas que desvelan las redes de poder y visibilizan las conexiones entre el neoliberalismo y las guerras geoeconómicas. Esto puede observarse en las imágenes de Larry Fink, quien recurre a la escenificación y recreación de escenas conocidas partiendo de las pinturas de George Grosz, como es el caso de Homenaje a George Grosz (200I), ${ }^{13}$ fotografía de gran formato que parte de una polémica serie prohibida en Estados Unidos, en la que aparece George Bush con la mano en el pecho de una mujer, lo que resultó para la doble moral americana muy ofensiva. Larry Fink explica, "la mujer debe entenderse como metáfora de nuestra política exterior. [...]. Creo que es una imagen apropiada para lo que estamos haciendo en política exterior: palpar a ciegas sin comprender verdaderamente qué estamos haciendo y aprovecharnos de nuestro imperioso poder" ${ }^{14}$ Larry Fink representa a los grandes líderes de Estados Unidos (fig. 2), desde una formalización neobarroca, con una mirada irónica en la que parece corroborar lo que planteaba Foucault, y visibilizar

I2. Esta serie de obras se mostró en la exposición que tuvo lugar en Dvir Gallery (Tel Aviv) del 4 de enero de 2007 al 2 de febrero de 2007. Las imágenes referidas y mayor información sobre las mismas pueden consultarse en los siguientes enlaces: https://kadist.org/work/hebron/, y http:// dvirgallery.com/exhibition/solo-show-7/, consultados el 25 de junio de 2019 .

I3. Esta obra es una fotografía de gran formato, cuyas medidas son $136.9 \times$ III. $8 \mathrm{~cm}$. Puede consultarse más información y acceder a la imagen referida en la página web de la galería en la que fue expuesta la serie: www.lichtblicknet.com/ausstellungen/index.php?id=I44, consultada el 25 de junio de 2019 .

I4. David Arranz y Javier Panera, comps., Mascarada (Salamanca: DA2, 2007), 24. 


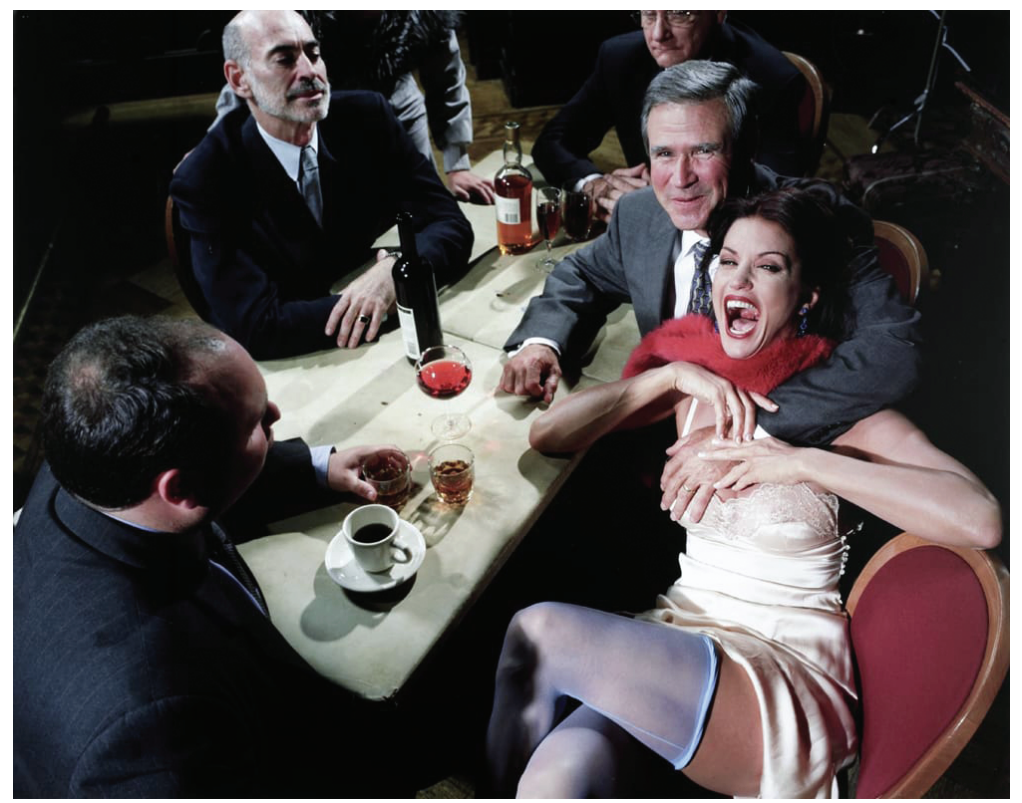

2. Larry Fink, Homenaje a George Grosz, fotografía, 20or. Tomada de: http://www. artnet.com/Magazine/reviews/walrobinson/robinson7-20-3.asp

mediante estrategias icónicas las potencialidades de las imágenes artísticas para descifrar los desplazamientos de poder y las relaciones de fuerza en los conflictos bélicos contemporáneos:

la política como guerra continuada con otros medios sería en este primer sentido un dar la vuelta al aforismo de Clausewitz; es decir, la política sería la corroboración y el mantenimiento del desequilibrio de las fuerzas que se manifiestan en la guerra. Pero la inversión de esta frase quiere decir también otra cosa: en el interior de esta "paz civil", la lucha política, los enfrentamientos por el poder, con el poder, del poder, las modificaciones de las relaciones de fuerza, las acentuaciones en un sentido, los refuerzos, etc., todo esto en un sistema político no debe ser interpretado más que como la continuación de la guerra, es decir, debe ser descifrado como episodios, fragmentos, desplazamientos de la guerra misma. ${ }^{\text {Is }}$

15. Michel Foucault, Microfisica del poder (Madrid: La Piqueta, 1992), I02. 
La obra de Fink conjuga la parodia con otra estrategia muy utilizada por los artistas contemporáneos para forzar una conciencia crítica. ${ }^{16}$ Frente a las imágenes propias de los medios periodísticos, a las imágenes documentales, la creación de imágenes escenografiadas permite, más allá de reflejar la supuesta realidad, construir una realidad que analice la complejidad de los conflictos bélicos. "Buena parte de estos autores se plantean la codificación de sus inquietudes intelectuales a través de la construcción artificial de las situaciones que fotografían, a modo de tableaux vivants, o puestas en escena minuciosamente preparadas". ${ }^{17}$ Como parte de esta estrategia se sugieren dos acercamientos: I) aquellos que ponen de manifiesto la artificialidad con la que está construida la imagen, y 2) aquellos que se adecúan con fidelidad a la estética de lo real para crear un juego de ficciones. "Mientras que la representación intenta absorber la simulación interpretándola como falsa representación, la simulación envuelve todo el edificio de la representación tomándolo como simulacro". ${ }^{18}$

Estas imágenes tienen un gran potencial narrativo, discursivo y presentan hibridaciones con otras disciplinas como el cine, la pintura, la literatura o la publicidad. De la estrategia de evidenciar la construcción de la escena se consiguen varias cuestiones que van en pro del discurso emancipador de estas imágenes. Por un lado, de manera significativa los artistas que abogan por estos modos de hacer reflexionan sobre el acto de relatar. La imagen se establece como relato icónico que cuestiona su carácter representativo,

la imagen no se reduce a su visibilidad, la visibilidad no es un criterio determinante ni el único; participan procesos que la producen y pensamientos que la sustentan [...]. La fotografía digital es consecuencia de una economía privilegiada de la información como mercancía, los capitales opacos y las transacciones telemáticas invisibles. [...] Responde a un mundo acelerado, a la supremacía de la velocidad vertiginosa y a los requerimientos de la inmediatez y la globalidad. Se adscribe en definitiva a una segunda realidad o realidad como ficción. ${ }^{19}$

I6. Un estudio relevante sobre la obra de Larry Fink que puede consultarse para ampliar la información sobre el autor es: Larry Fink, Donal Russo, Steve Salerno, Nelson Maniscalco, eds., The Forbidden Pictures: Photographs by Larry Fink, o7/Ig/oI (Bethlehem: Lehigh University, 2004).

17. José Gómez Isla, Fotografía de creación (Madrid: Nerea, 2005), 73.

I8. Jean Baudrillard, Cultura y simulacro, trads. Antoni Vicens y Pedro Rovira (Barcelona: Kairós, 2005), I7-I8.

19. Joan Fontcuberta, La cámara de Pandora.La fotografi@ después de la fotografía (Barcelona: Gustavo Gili, 20I7), I2. 
Los escenarios que se construyen para ser fotografiados plantean virar constantemente entre la imagen fija y la imagen móvil para convertirse en fragmentos de un acto performativo que sucede dentro de la imagen, pero también tiene continuidad en la afectación del cuerpo que la percibe. Una performatividad que permite tomas de postura y posicionamientos políticos. Desplazamientos subjetivos entre las imágenes y los cuerpos que sienten y, en ese sentir, se ven interpelados para tomar voz en esos relatos icónicos no lineales propios de las imágenes. En la obra de Michael Najjar, Embedded (2003), ${ }^{20}$ se ponen en marcha esas cuestiones a partir de la manipulación de la información de los medios. La obra combina elementos realistas, realidad ficcionada y ficción para ofrecer otra perspectiva que cuestione el discurso oficial. Investiga las estrategias y los recursos utilizados normalmente en los medios de comunicación, que el espectador identifica como signos de la imagen de lo real, a pesar de ser artificios manipulados para lograr esa vinculación: el tiempo real, el periodismo incrustado, las imágenes borrosas y la visión cinematográfica. ${ }^{21}$ "Hoy en día, la abstracción ya no es la del mapa, la del doble, la del espejo o la del concepto. La simulación no corresponde a un territorio, a una referencia, a una sustancia, sino que es la generación por los modelos de algo real sin origen ni realidad: lo hiperreal". ${ }^{22}$ De igual manera sucede en la serie Crónicas del crimen $(2006)^{23}$ de Wong Hoy Cheong. Se trata de una recreación de famosos crímenes cometidos en Malasia. Fotografías que ponen de manifiesto la composición de unos tableaux vivants en los que se sirve tanto de actores como de personas anónimas para, por medio de cierto aire irónico, denunciar estos asesinatos, hacerlos visibles. La construcción de las imágenes es evidente, no existe el fuera de campo, la acción no existe ni antes ni después del momento representado, una imagen ajustada hasta los más mínimos detalles que están compuestos con base en el imaginario propio de las películas de cine negro hollywoodien-

20. Esta obra es una fotografía en gran formato, de $100 \times 140 \mathrm{~cm}$ y forma parte de la colección del DA2 (Domus Artium, Salamanca). Puede consultarse en la siguiente url: http://domusartium2002.com/es/OBRA/embeddeddelaserie, consultada el 25 de junio de 20I9. Otro estudio que analiza la trayectoria del artista es: Mark Amerika, Sean Cubitt, John Gotto, Andreas MüllerPohle, "Photography and Beyond: On Vilém Flusser's, Towards a Philosophy of Photography", Flusser Studies, núm. Io (2010): I-24.

2I. Véase David Arranz y Javier Panera, comps. Mascarada (Salamanca: DA2, 2007).

22. En Baudrillard, Cultura y simulacro, 9.

23. Las fotografías que componen la serie pueden verse en la bibliografía específica en http:// www.teppertakayamafinearts.com/wong_hoy_cheong/ooo2.html, consultado el 25 de junio de 2019. 
ses. "Tras el barroco de las imágenes se oculta la eminencia gris de la política". ${ }^{24}$ La utilización de la iconografía propia de una cultura complejiza la situación en la medida que la interpelación se produce mediante elementos culturales particulares que son comprensibles únicamente para una determinada comunidad. Sirva como ejemplo de esta estrategia la serie Four Beauties. Wang Zhaojun $^{25}$ (2004) de Liu Zheng, quien construye escenas en las que mezcla la tradición y modernidad chinas. Las cuidadas composiciones, en las que prima lo estético, tienen reminiscencias teatrales. La serie Four Beauties aborda los temas de la guerra y del amor, por medio de personajes inspirados en la ópera tradicional china. Trasladar elementos específicos a las imágenes que puedan ser descifrados únicamente por aquellos que comparten determinados sesgos culturales fuerza la identificación del espacio connotativo de las mismas mientras que éstas pierden universalidad. En este sentido, puede analizarse la obra de Aura Rosenberg, Angel of History (Thames) (2005), ${ }^{26}$ que parte de Angelus novus de Paul Klee, que describe Walter Benjamin en su libro Theses on the Philosophy of History. ${ }^{27}$ Con una voluntad de transformar en nuevas imágenes las descripciones que Benjamin plantea en su texto, construye una serie de collages fotográficos que estructura en tres partes o niveles de lectura: el fondo es el futuro, el espacio intermedio está compuesto por ruinas de guerra y arquitecturas derruidas y en primer término aparece el ángel de referencia. Desde el punto de vista formal son obras que dejan en evidencia su construcción por medio de un software de manipulación de imágenes, para establecer distintas capas fácilmente distinguibles que muestran, por un lado, el carácter construido de la fotografía y, por otro, una consonancia conceptual con lo planteado.

En relación con la otra estrategia significativa de escenificación de situaciones que devienen en imagen, podrían citarse como elementos articuladores de las mismas un juego con la estética de lo real para construir las imágenes sobre lo bélico. La obra de An-My Lê es paradigmática en este sentido. En su serie Small Wars (1999-2002) ${ }^{28}$ puede comprobarse cómo la formalización de

24. Baudrillard, Cultura y simulacro, I6.

25. Esta serie fotográfica puede consultarse en: http://archive.bampfa.berkeley.edu/mahjongartists/liu/_zheng.html, consultado el 25 de junio de 2019.

26. Las imágenes que componen esta serie, así como mayor información sobre las mismas, pueden verse en www.europeanmonthofphotography.org/? $\mathrm{p}=573$, consultado el 25 de junio de 2019 .

27. Tesis sobre la historia y otros fragmentos, trad. Bolívar Echeverría (Ciudad de México: Ítaca/ Universidad Autónoma de la Ciudad de México, 2008).

28. Puede consultarse la imagen y las características de la misma en www.guggenheim.org/ 


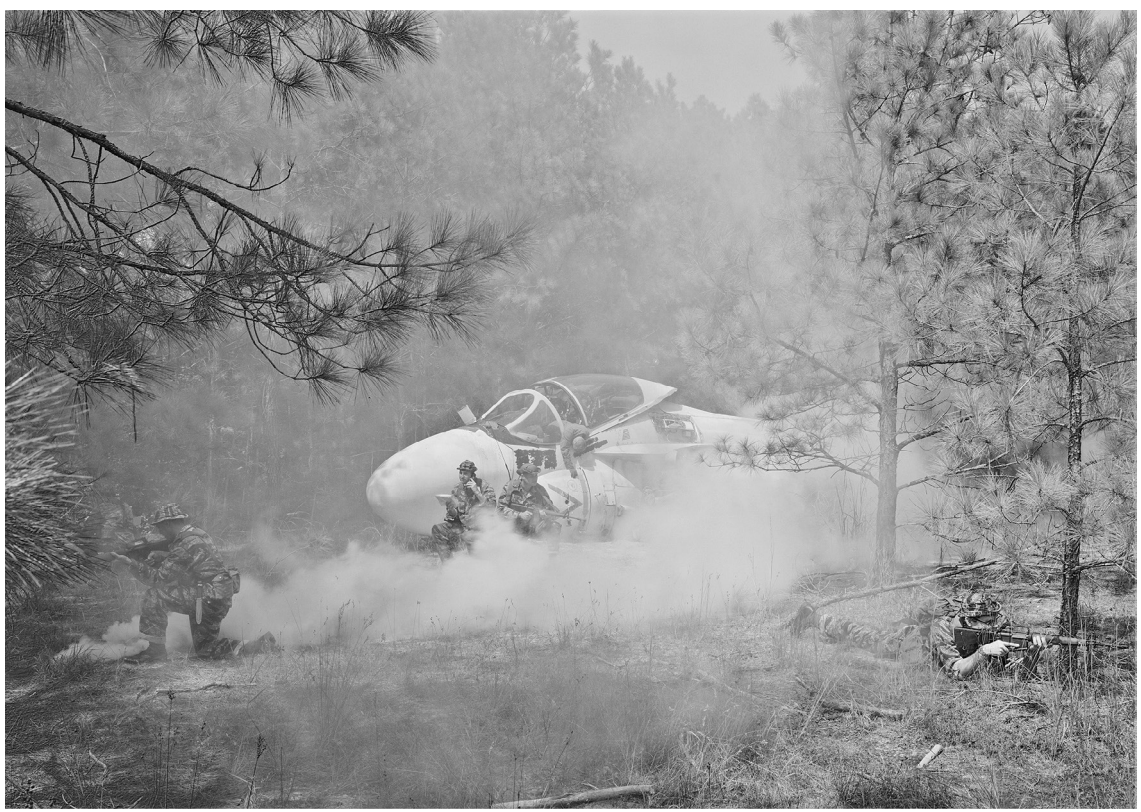

3. An-My Lê, Small Wars: Rescue, fotografía, 1999-2002 (C) An-My Lê.

la fotografía se centra en la escala de grises y en la iluminación propia de escenas de exterior que remite, de manera explícita, a las fotografías documentales clásicas, en las que recrea las batallas que tuvieron lugar durante la guerra de Vietnam (fig. 3). Con una voluntad de conocer la historia en profundidad, tras un largo proceso de investigación, cuida todos los detalles que le permiten recrear un acontecimiento que se confunde con la realidad misma. La serie 29 Palms $^{29}$ (2003-2004) está compuesta de panorámicas del desierto californiano que recuerdan a las imágenes de guerra de Roger Fenton, recreando también escenas bélicas detalladas con gran minuciosidad. La artista busca una identificación del escenario de guerra con lo real, una coincidencia del simulacro con la realidad, pero se trata de unas imágenes carentes de sangre, asépticas,

artwork/2683, consultado el 25 de junio de 20I9. También se puede consultar la siguiente bibliografía específica: An-My Lê, "Small Wars", 2, Cabinet (primavera de 20oI). Disponible en http:// www.cabinet magazine.org/issues/2/smallwars.php.

29. Puede consultarse la imagen referida en https://sheldonartmuseum.org/exhibitions/anmy-I\%C3\%AA-29-palms, consultado el 25 de junio de 2019. Para mayor información sobre la trayectoria artística de la autora véase: http://www.anmyle.com/, consultada el 25 de junio de 2019. 
demasiado generales que nos relatan una lectura más conceptual que real, que pueden leerse en términos simbólicos. De alguna forma, parece que dentro de la descontextualización está dejando fuera el contenido histórico-político que da origen a la guerra.

No sólo la decadencia del Estado ha hecho factible los procesos de virtualización [...]. El papel de las tecnologías con sus efectos de deslocalización y descorporización han permitido la desterritorialización y reterritorialización de los conflictos. Especialmente el papel de las Tics con la apertura de nuevos escenarios que permiten la intervención de nuevos sujetos. Los procesos de virtualización de la guerra la han constituido en una guerra global, permanente. Una guerra que (re) produce la vida constantemente..$^{30}$

Existe una necesidad de forzar el significado de dichas imágenes más allá de la fotografía documental que ha condicionado los elementos icónico formales que configuran este tipo de fotografías de guerra. En la medida en que se separan de lo documental estas imágenes permiten, como en el caso anterior, la entrada a lo sensible que fuerza un posicionamiento subjetivo más allá de la visión contemplativa. Estas fuerzas que confluyen para desmentir la veracidad de la imagen se dan de forma magistral en las obras de Joan Fontcuberta. En Deconstruir Ossa$m a^{31}$ (2004) sigue la línea que comenzó con la obra Sputnik (1997), creando una historia documentada con textos e imágenes en la que, jugando con los límites

30. Ballaz y Folch, "Virtualización y actuaciones del estado-guerra", consultado el 30 de julio de 2018.

3I. En este proyecto Joan Fontcuberta presenta una historia compuesta de textos e imágenes, en la que relata cómo el gobierno de Estados Unidos mediante la Oficina de Influencia Estratégica habría creado al personaje de Bin Laden con la finalidad de encontrar lo antes posible un culpable, una cabeza visible, a los atentados del ir de septiembre de 200I. Este personaje, interpretado por un actor de nombre Mohamed Ben Youssuf, aparecía retratado en una serie de tomas escenografiadas de referencia formal documental. Una vez destapado el engańo, en un doble juego, el gobierno de Estados Unidos vuelve la estrategia contra sus adversarios, reseñando el poder malévolo de Bin Laden al tratar de utilizar un doble para engańar a los servicios de inteligencia americanos. Fontcuberta en un juego de pistas falsas con referencias reales impone al espectador el germen de la duda, una duda necesaria que cuestione la información y las imágenes que percibimos habitualmente y que construyen un mundo a medida en una red de poder. Véase la siguiente bibliografía específica: Gabri Ródena, "Capturar es compartir. Filosofía, redes sociales y fotografía 2.0", Enrahonar. Quaderns de Filosofía, núm. 20 (2013): 59-72. La trayectoria artística de Joan Fontcuberta transcurre en paralelo al analisis crítico de las prácticas artísticas fotográficas contemporáneas, en este sentido, se recominenda consultar los textos: Joan Fontcuberta, El beso 
entre ficción y realidad, enfrenta al espectador a la disyuntiva de creer lo que está viendo, a pesar de tratarse de un relato construido. En palabras del propio autor "la fotografía nos resulta equívoca quizá porque la realidad a la que se refiere lo es todavía más". ${ }^{32}$

Estos modos de fisurar el imaginario de la fotografía documental, en ocasiones no parten de una construcción de escenas sino que se sirve de la fragmentación y descontextualización de elementos tomados directamente de los medios de comunicación y redes sociales. Es el caso de Aernout Mik quien produce sus obras a partir de fragmentos que extrae de diversas agencias de noticias, los monta en un loop doble consecutivo que presenta imágenes que no

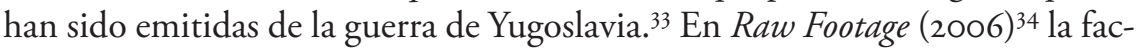
tura formal propia de los medios de comunicación le da una lectura que entra dentro de lo que habitualmente percibimos como real debido a los códigos que hemos ido adquiriendo a partir de la percepción de las imágenes periodísticas. El espectador se ve enfrentado a preguntarse sobre la verosimilitud de la imagen. Las escenas de estas imágenes rescatadas contrastan con la apariencia formal de las mismas cuyo contenido, al contrario que su factura, no se identifica con lo que solemos ver en televisión, mientras es inevitable preguntarse por qué esas imágenes no fueron nunca emitidas, cuáles son los criterios que sirvieron para desecharlas. En todos estos casos, la afectación y el quiebre entre lo real y la representación son clave para la reflexión crítica en la que la toma de postura del espectador se vuelve necesaria. Puede comprobarse, también, en la obra Vietnam, 1967, near Duc Pho (200I),35 en la que David Claerbout reproduce la escena del derribo de un avión que tuvo lugar hace 40 años.

de Judas. Fotografia y verdad (Barcelona: Gustavo Gili, 1997) y Joan Fontcuberta, La furia de las imágenes. Notas sobre postfotografia (Barcelona: Galaxia Gutenberg, 2016).

32. Joan Fontcuberta. Deconstructing Osama, http://www.fontcuberta.com/, consultado el 30 de julio de 2018.

33. Para mayor información sobre el autor consúltese: Patricia Pisters, "Image as Gesture: Notes on Aernout Mik's Communitas and the Modern Political Film", Journal for Cultural Research I, núm. i9 (2015): 69-8I, DOI: I0.I080/I497585.20I4.920I89 y Sylvia Martín, Video Art. Cologne (Colonia: Taschen, 2006) y para información específica sobre los procesos de su obra véase el documental "Aernout Mik: A sense of Univertainty", en https://vimeo.com/ı16859837, consultado el 25 de junio de 2019.

34. Fotogramas de esta serie pueden verse en http://old.mg-lj.si/node/93, consultado el 25 de junio de 2019 .

35. Esta obra es un video monocanal, con una duración de 3 min en loop. Véase el siguiente enlace, https://davidclaerbout.com/Vietnam-1967-near-Duc-Pho-reconstruction-after-Hiromishi- 
Utiliza el video para reconstruir una fotografía realizada por Hiroshimi Mine. "Claerbout confiesa no inventar situaciones — siempre parte de un fotograma o fotografía existente; así sus obras responden a una realidad matizada, una realidad levemente pervertida que deja el ánimo del espectador en suspenso". ${ }^{36}$

\section{Renegociando la historia. Las huellas de la guerra y la memoria}

Una de las conexiones que se establece entre las obras que reflexionan sobre el objeto de investigación es un acercamiento al final de los grandes relatos de la historia, expuesta por Lyotard ${ }^{37}$ para realizar una relectura de los grandes acontecimientos bélicos e históricos del siglo xx. Con base en cuestiones de carácter más íntimo realizan unas obras artísticas que guardan tras de sí una renegociación con la historia y sus consecuencias, una forma de incidir en la memoria colectiva que, a su vez, funcione de manifestación y asunción del trauma, un duelo colectivo y, a la vez, unos traumas personales escritos en primera persona. Rancière expone, en su formulación del "triple contrato", que la historia es un contrato científico, en la medida que investiga sobre el orden oculto, pero también se trata de un contrato narrativo, que posiciona acontecimientos y personajes en un desarrollo con principios y fines. En último caso, expone, es un contrato político que vincula los contratos anteriores con las situaciones propias de la era de masas, véase, las democracias, las revoluciones, las contrarrevoluciones, para acabar mostrando una historia común que sea comprensible y legible para todos. ${ }^{38}$

Las prácticas artísticas, que trabajan desde las memorias particulares, se establecen como ejes para esa reivindicación de una historia en plural, capaz de acoger los múltiples relatos que la componen. Es en este sentido como puede analizarse la obra de Boltanski, él reconstruye lo que denomina "pequeña memoria". 39

Mine-200I, consultado el 25 de junio de 20I9. Para mayor información sobre el autor se recomienda visitar su página web, https://davidclaerbout.com/, consultada el 25 de junio de 2019.

36. David Barro, Antes de ayer y pasado mañana o Lo que puede ser pintura hoy (La Coruña: Arte Contemporáneo y Energía/AIE-MACUf/Artedardo, 2009), I46.

37. Jean-François Lyotard, La condición posmoderna (Madrid: Cátedra, 2006).

38. Jacques Rancière, Els Noms de la història. Una poètica del saber (Valencia: Universitat de València, 2005).

39. La "pequeña memoria" es, para Christian Boltanski, una memoria emocional, tal y como cita Estrella de Diego en el artículo: "La pequeña (y no tan pequeña) memoria", El País, 
Centrado en el tema del holocausto, esa memoria privada trata de recordar a los muertos anónimos, presentando sus instalaciones como una experiencia particular en la que parece hablarnos de una experiencia compartida, de unos muertos comunes. Boltanski nos enfrenta en sus obras a una serie de elementos recurrentes que constituyen su lenguaje creativo, unos polípticos de gran número de fotografías de archivo de rostros anónimos, rostros que con la acumulación, la reiteración, reafirman su anonimato. ${ }^{40} \mathrm{~A}$ menudo, incorpora a su obra otros elementos como ropa vieja, que hacen patente la ausencia del cuerpo. Con la estrategia de la negación alude a la fisicidad del individuo como símbolo de vida y, en su ausencia, como símbolo de muerte. Juega a menudo con la luz, incorporando pequeñas fuentes lumínicas que también funcionan como metáfora de vida y juega a la idea del espectro, de la sombra, del reflejo dando forma al recuerdo. "Entonces, como suele hacerse incluso con los muertos más insignificantes, reunieron los recuerdos que él hubiera podido dejarles, ayudándose unos a otros y esforzándose por ponerse de acuerdo. Pero conocemos esta llamita, esos temblores en la sombra turbada. Y el acuerdo sólo llega más tarde, con el olvido". ${ }^{41}$ La recurrencia de estrategias de archivo es clave para fijar en la obra la multiplicidad de puntos de vista que cuestionan la historia y que posibilitan la entrada del recuerdo, de los afectos y de la vida en comunidad como aspectos clave de la relectura, desde el presente, de los acontecimientos del pasado. Las referencias al archivo también son constantes en su obra,

¿qué fantasmas hablan — comparecen — entonces en estas memorias? En las de archivo, está claro eran fantasmas del pasado, presencias de tiempos otros-anteriores que retornan al nuestro. [...]. Toda memoria hypomnémica juega en efecto la

Suplemento Babelia, 30 de enero de 20Io. Disponible en https:elpais.com/diario/20Io/or/30/. babelia/I24813953_850215.html, consultado el 25 de junio de 2019. Se puede acceder también a una reflexión crítica sobre este concepto en: Carmen Alval Beltrá, "Christian Boltanski y la memoria de los objetos", Eu-topías: Revista de Iterculturalidad, Comunicación y Estudios Europeso, núm. I2 (20I6): 23.

40. Un ejemplo de este tipo de obras es: "Archives de l’Année $1987 \mathrm{du}$ Journal El Caso", que forma parte de la Colección de Arte Contemporáneo de La Caixa véase https://coleccion.caixaforum. com/obra/-/obra/ACFo429/Archivosdelanoi987dedarioiElCasoi, consultado el 25 de junio de 2019. En la monografía se puede consultar un análisis crítico de la obra de este artista, en Anna María Guasch, Arte y archivo, I920-2010: genealogía, tipología y discontinuidades (Madrid: Akal, 20II).

4I. Samuel Beckett, Malone meurt, trad. Ana María Moix (Madrid: Alianza, 1973). 
fuerza de un conocer que se produce siempre como anámesis — como recuerdo y reposición de un saber "ya tenido", del que es siempre recordatorio, memento. ${ }^{42}$

Cuando nos enfrentamos a los muertos de Boltanski parece que tratamos de encontrar dentro de ese sinfín de fotografías de personas anónimas que pueblan sus instalaciones, aquella persona cercana que perdimos. Nos involucramos en una experiencia de duelo que es la de miles de personas pero, en realidad, no es la nuestra, con una cercanía y una intimidad propias de una historia personal vivida y, en ese momento, recordada, traída hasta el presente. Una memoria individual que es remitida a la memoria pública, colectiva. "Si la historia es un consenso y la memoria un acuerdo, recordamos lo que colectivamente nos ayudan a recordar. La Historia con mayúsculas es un relato que se ha hecho hegemónico". ${ }^{43}$ Diferente es el acercamiento de Anselm Kiefer. En este caso la estrategia utilizada no es la fragmentación del relato histórico y la recuperación de las historias particulares sino que se sigue haciendo énfasis en el relato histórico hegemónico construido para abordar el sentimiento de culpa colectivo. ${ }^{44}$ Kiefer reflexiona en sus obras sobre el pasado de Alemania. Inserto en su cultura e imaginario, el artista alemán investiga la culpa de una sociedad que encuentra en el silencio y la ocultación la manera de sobrellevar la culpa. Más allá de la memoria privada de Boltanski, Kiefer alude a la historia a partir de su mitología con el objetivo de acabar con el tabú del olvido. Por medio de un lenguaje informalista, presenta grandes paisajes desolados, formatos de grandes dimensiones que funcionan como monumentos en ruinas a la memoria de la barbarie en los que convergen alusiones a la cultura alemana, a la filosofía, a la literatura y a la mitología. Paisajes reducidos a escombros y cenizas como metáforas del duelo,45 "sin duda Anselm Kiefer es un pintor estrechamente vinculado a la muerte y al desierto puesto que sus cuadros son el paisaje del fin del

42. José Luis Brea, Cultura RAM (Madrid: Gedisa, 2007), 8, http://www.jose-fernandez. com.es/wpcontent/vploads/2013/o6/Cultura_RAM-Brea-Jose-Luis.pdf, consultado el 23 de septiembre de 2019 .

43. Estrella de Diego, El final de los grandes relatos (Madrid: Juan March, 2003), www.march. es/conferencias/anteriores/voz.aspx?pI=2178, consultado el 30 de julio de 2018.

44. Puede consultarse bibliografía crítica sobre la obra y discursos del artista en las siguientes monografías: Lisa Saltsman, Anselm Kiefer and Art after Auschwitz (Cambridge: Cambridge University Press, 1999) y Matthew Biro, Anselm Kiefer and the Philosohy of Martin Heidegger (Cambridge: Cambridge University Press, 1998).

45. Estas cuestiones pueden observarse en las obras como Seraphim (1983-1984) que puede consultarse en: www.guggenheim.org/artwork/2082, consultado el 25 de junio de 2019 , y Urd, 
mundo, un paraje inhóspito en el que no hay refugio, en el que la historia ha arrasado por completo y del que no parece haber escapatoria posible". ${ }^{46}$ Freud sostenía que el duelo es una separación de la actitud normal ante la vida ${ }^{47}$ y Kiefer analiza el duelo desde la conciencia del poder sanador del arte, como Beuys opinaba que es necesario mostrar las heridas para poder sanarlas. "Más que una conmemoración nostálgica lo que está en juego en estos trabajos es la tarea de ser un artista alemán cuando los elementos de la identidad alemana han sido eficazmente puestos al servicio de la devastación" . $4^{8}$

Otra de las estrategias utilizadas para forzar una visión crítica de la historia es generar elipsis visuales forzando que sea el propio espectador el que recomponga los acontecimientos. En este caso existe normalmente una fragmentación de las imágenes, que a menudo forman polípticos y, también, la inserción de elementos ambiguos que permiten abrir la lectura más allá de lo explícito de las imágenes documentales. De ahí que uno de los recursos significativos sea investigar estas cuestiones a partir del medio pictórico. La elección de la pintura implica también una referencia a la pintura de historia que, por un lado, legitima los acontecimientos que se muestran mediante unos modos de mirar heredados de la tradición del género y, por otro, los cuestiona a partir de la contraposición de elementos significativos y banales. Esto es, precisamente, lo que plantea Luc Tuymans. En la Bienal de Venecia de 200I, Tuymans presentó la serie Mwana Kitoko (2000) que reflexionaba, en Io cuadros, sobre la actuación de Bélgica en el Congo. ${ }^{49}$ La traducción del título de la obra es "Niño bonito blanco", nombre irónico con el que nombraban al rey Balduino I, coronado muy joven tras la abdicación de su padre por su implicación con los nazis. A lo largo de las obras que componen la serie, Tuymans analiza aspectos clave de la acción colonialista belga: la explotación colonial, la modernidad y su influencia en la civilización, la Iglesia, la imagen turística, el asesinato de Lumumba, entre otros. "Somos los espectadores quienes debemos

Verdandi, Skuld (The Norns) (1983) disponible en: https:/www.tate.org.uk/artistis/anselm-kiefer-I406, consultado el 25 de junio de 2019 .

46. Esther Terrón Montero, "Anselm Kiefer. La memoria", Cuadernos del Ateneo, núm. Is (2003): I5I.

47. Sigmund Freud, "Duelo y melancolía", en Sigmund Freud, Obras Completas (Buenos Aires: Amorrortu Editores, 1993).

48. Terrón Montero, "Anselm Kiefer. La memoria”, I48.

49. Pueden consultarse las obras que componen la serie en el siguiente enlace: www.davdzwirner. com/exhibitions/mwana-kitoko-beautiful-whie-man, consultado el 25 de junio de 2019 . 
reconstruir los acontecimientos a partir de unas pruebas poco sólidas desdibujadas por el paso del tiempo. [...]. El carácter de la obra inconclusa resulta crucial; estamos ante síntomas, necesariamente fragmentarios, de traumas, de una culpa no reconocida". ${ }^{50}$

La pintura es, también, el medio a partir del cual legitimizar las imágenes históricas. Si el género de la pintura de historia se ocupó durante siglos de dar testimonio de acontecimientos relevantes escritos en la historia desde el poder, ahora sirve para algunos artistas como medio legitimador de imágenes que visualizan hechos y acontecimientos significativos que han sido censurados o clasificados. Gamaliel Rodríguez, en Issues (2011) ${ }^{\text {sI }}$ parte de fotografías desclasificadas de experimentos que tuvieron lugar durante la guerra de Vietnam en los que los individuos eran expuestos a radiación nuclear y a herbicidas ("agente naranja").

Las interpretaciones alternativas (inclusive rivales) de ese pasado reciente y de su memoria comienzan a ocupar un lugar central en los debates culturales y políticos. [...] Esas memorias y esas interpretaciones son también elementos clave en los procesos de (re-)construcción de identidades individuales y colectivas en sociedades que emergen de periodos de violencia y trauma..$^{52}$

Estos experimentos, que tuvieron lugar en Puerto Rico, hablan de cómo la huella de la barbarie toma forma física en los cuerpos. A partir de dichas fotografías, Rodríguez pinta unos cuadros de gran formato, incidiendo en las huellas que dichos ensayos dejaron sobre la fisiología de los cuerpos y los daños que provocaron en las víctimas, y obliga al espectador a no olvidar las atrocidades que suelen acompańar a los conflictos bélicos.

El medio pictórico sirve, asimismo, para representar lo irrepresentable, como en el caso de Stephen Ellis en el que la imagen se torna texto, en They Feed the Lion (2003).53 La incapacidad del artista por representar la situación que se produjo tras el in de septiembre encuentra forma en los poemas de Phi-

50. Barro, Antes de ayer y pasado mañana, 321.

5I. Esta serie de cuadros estuvo expuesta en la Galería Espacio Mínimo (Madrid), en la galería de las obras que conforman la citada serie, http://www.espaciominimo.es/en/gamaliel-rodriguez, consultado el 25 de junio de 2019 .

52. Elizabeth Jelin, Los trabajos de la memoria (Madrid: Siglo XXI, 2002), 5.

53. Esta obra es un óleo sobre lienzo y tiene unas dimensiones de $127 \times 213.4 \mathrm{~cm}$, véase http:// vonlintelgallry.blogspot.com/20Io/04/stephen-ellis-selected-works.html, consultado el $25 \mathrm{de}$ 
lip Levine. Tras el atentado, Ellis trató de buscar una información que le ayudara a esclarecer lo ocurrido, para ello investigó en Internet lo que los distintos medios de comunicación, las redes sociales o canales alternativos de información aportaban al tema. Incapaz de encontrar su objetivo, empezó a indagar en la poesía como punto de partida para acabar representando lo irrepresentable.

Puede darse el caso de que la pintura se combine con otros medios como el dibujo, el video o el texto para mostrar, mediante un acercamiento múltiple, la multiplicidad de la imagen en la contemporaneidad y su relación con la conformación y resignificación de los relatos históricos en tiempo presente. Esa suerte de dislocación forzada a partir de la heterogeneidad de los medios utilizados, sirve como estrategia artística para inducir una reconstrucción que visibilice la imposibilidad de acercarse desde un único punto de vista a un acontecimiento dado. Al igual que Gamaliel Rodríguez, el artista chino Sun Xun destapa casos de censura y ocultación de datos que visibilizan los modos en los que la historia de estos acontecimientos se construye desde el poder. La instalación $L a$ aeronave de Ceaucescu (2009) $)^{54}$ explora los sucesos que precedieron a la captura y la ejecución del líder comunista rumano Ceausescu en 1989. Una intervención en las paredes del espacio expositivo que combina dibujo, pintura, video y texto y que trae al presente la historia de la dictadura. Desvinculándose del discurso oficial, Sun Xun trata de recomponer lo acontecido, a base de fragmentos e ideas, cuestionando el modo en que el poder relata su visión de los hechos y cómo estas narrativas son catalizadas por la censura, el silencio y la ocultación.

De forma general, los mecanismos de poder nunca han sido muy estudiados en la historia. Han sido estudiadas las personas que detentaban el poder. Se trataba de la historia anecdótica de los reyes, de los generales. A ésta se le ha opuesto la historia de los procesos, de las infraestructuras económicas. A su vez a ésta se ha opuesto una historia de las instituciones, es decir, aquello que se considera como superestructura en relación a la economía. Ahora bien, el poder en sus estrategias, a la vez generales y afinadas, en sus mecanismos, nunca ha sido muy estudiado. 55

junio de 2019. Un acercamiento crítico a esta obra puede consultarse en Tony Godfrey, Painting Today (Londres: Phaidon, 2009).

54. Pueden verse imágenes de la instalación en: www.artlinkart.com/en/artist/wrk_sr/55Iawv/20fawtn, consultado el 25 de junio de 2019.

55. Foucault, Microfísica del poder, 74. 
Ilya Kabakov en 10 personajes (198I-1988) aborda, ${ }^{56}$ al igual que Boltanski, la deconstrucción de la historia a partir de la confluencia de las pequeñas memorias individuales, en las que las pérdidas y la ordenación de la memoria son elementos clave. En este caso se ponen en marcha dos estrategias ya analizadas, en primer lugar la conformación de un relato histórico por medio de la presentación de las memorias individuales y el entrecruzamiento de las mismas con la historia hegemónica. En segundo lugar, se plantea un énfasis en la recreación de espacios y escenas. En Ilya Kabakov vemos cómo convergen estas dos estrategias detectadas. La conformación del relato histórico puede entenderse a partir de la suma de una pluralidad de memorias y, en consecuencia, de subjetividades políticas. Este artista ruso reflexiona sobre el homus sovieticus mediante unas obras que impactaron en el panorama artístico neoyorquino de finales de 1980. Io personajes presenta la vida inventada de una serie de personas, habitantes de las comunarcas rusas. Kabakov muestra, en álbumes, la historia verosímil que inventa para cada uno de ellos, esa historia que es ficción pero que, tanto por su factura como por su contenido, podría ser cierta, inventando la historia, para paradójicamente, preservar la pérdida. Estos paseos por la memoria rusa construyen una historia paralela a la impuesta, una historia que contiene las vidas de aquellos que la vivieron en pasado y que son capaces de recordarla a partir de sus experiencias más cotidianas. Los recuerdos se apoyan en las experiencias pasadas, pero se resignifican desde el presente. La posibilidad de reconstruir el pasado desde el presente supone una capacidad de renegociación continua en el que las historias, ahora plurales, dinámicas y flexibles, se reconstruyen, pero también se deforman.

Los artistas presentados pretenden, mediante unas estrategias que parten de la imagen como unidad de significado, investigar justo lo que Foucault analizaba, los mecanismos del poder en los que están sustentados los discursos por medio de los cuales conocemos nuestro pasado, que sirven, de algún modo, para cimentar nuestro presente. ${ }^{57}$ Lo hacen además intentando romper estos discursos en "mil pedazos" y recomponer de nuevo la historia, pero no una historia única, no la Historia con mayúsculas, sino una de las posibles historias

56. Para más información sobre la obra del artista, así como sobre las imágenes de la instalación que se citan en este artículo puede consultarse: Tom Stoos, ed. Oskar Batschmann, Boris Groys, Robert Storr y Rod Megham, Ilya Kabakov: installations 1983-200o. Catalogue raisonné (Düsseldorf: Richter Verlag, 2003).

57. Foucault, Microfisica del poder. 
que podrían ser contadas, el final de los grandes relatos que deja paso a una realidad multifacética. Es por ello por lo que una de las estrategias artísticas más utilizadas va a ser la configuración de unas obras múltiples, que simbolizan la multitud de puntos de vista representados. Si se comparan estas piezas con las obras más características del género de la pintura histórica, puede observarse cómo la fragmentación y la seriación se han convertido en elementos clave de la representación, y que este fraccionamiento está compuesto por la variedad de sucesos, de personajes y de tiempos que conviven desde una estructura que deja claro desde el principio que no es lineal, pero que se acerca a una unidad capaz de representar una verdad no categórica.

\section{A contracorriente. El campo de batalla está en la calle}

La sociedad civil no ha permanecido inmune a la globalización de la guerra. Una serie de resistencias localizadas han servido para visibilizar el descontento de una sociedad que, en gran parte, cuestiona los modos neoimperialistas que definen nuevos acercamientos a lo bélico.

Las manifestaciones y la contestación de la sociedad contra la guerra de Vietnam marcó un hito en lo que a resistencia civil se refiere. Un movimiento antibelicista tomó la calle en Estados Unidos y después se extendió de distintas formas, con objetivos y puntos de partida distintos, a diferentes lugares del mundo. Podría decirse que el mayo francés de 1968 tiene, también, su génesis en una voluntad antibelicista (guerra de Indochina y Argelia). Los años ochenta supusieron igualmente una década de movilización social como respuesta a la era de conservadurismo impuesto por la administración de Reagan y posteriormente la de Bush. Las luchas sociales en contra de la política regresiva y conservadora plantearon una denuncia de cuestiones como la integración racial, las reivindicaciones feministas y de carácter identitario, la crisis del SIDA, el apartheid, entre otros.

Ya en el siglo Xxi han surgido una serie de protestas masivas que han tenido un impacto significativo en la visibilización de ese descontento social. La fuerza de estas acciones colectivas y los objetivos conseguidos por las mismas han variado dependiendo de los motivos, los apoyos y la fuerza del movimiento, pero no se puede negar que han permitido abrir un debate sobre las circunstancias base de las protestas y han cuestionado la hegemonía, los abusos, la manipulación y la imposición de un poder considerado intocable. "La responsabili- 
dad de la sociedad civil en el enfrentamiento y la resistencia contra las nuevas guerras geoeconómicas es hoy tal vez más grande que nunca [...]. La sociedad civil global necesita adquirir un papel central en articulaciones de resistencia"..$^{88}$

Las manifestaciones contra la guerra de Irak fueron masivas en muchas partes del planeta y evidenciaron que gran parte de la población consideraba que la invasión era ética y políticamente incorrecta y pusieron en duda la veracidad de los motivos esgrimidos para justificar la acción bélica. Una fuerza colectiva aunó un movimiento que convocó a miles de personas. La "primavera árabe" es el nombre que acuñaron los medios para las protestas y revoluciones que tuvieron lugar en distintos lugares del mundo árabe de 2010 a 20I2. En Espańa el movimiento I5-M ha supuesto también un punto de inflexión. Al partir de una voluntad de alejarse del sistema, este movimiento que se autodefine apolítico, intenta desvelar el fallo sistémico del sistema capitalista y encontrar vías alternativas con las que enfrentarse y solucionar los problemas a los que ha llevado el sistema económico y social actual. Para Rancière "España es ciertamente el país donde la primera condición se ha cumplido de forma más evidente: el movimiento ${ }_{5} 5-\mathrm{M}$ ha puesto claramente de manifiesto la distancia entre un poder real del pueblo y unas instituciones llamadas democráticas pero de hecho completamente entregadas a la oligarquía financiera internacional". 59 Los movimientos sociales, protestas y manifestaciones colectivas en los inicios del siglo Xxi han sido numerosos, una serie de movimientos de carácter local que han empezado a generarse de forma global en todo el mundo.

Es importante entender estos movimientos sociales de base colectiva como puntos de resistencia que no pueden medirse únicamente en función de la consecución de objetivos sino que deben también valorarse desde la intención de cambiar aquello que no responde a los intereses sociales de una población, aquello que viene impuesto y de lo que el ciudadano no quiere ser cómplice. En este sentido, las manifestaciones por la guerra de Irak no consiguieron parar la guerra, pero sí mostrar una red de contrapoderes en los miles de personas que alzaron una voz única. Quizá, está por verse que pueda decirse lo mismo del movimiento I5-M, el cual ha conseguido una visibilidad sin precedentes y el sentimiento de una colectividad unida.

58. Oslender, "Construyendo contrapoderes a las nuevas guerras", 74.

59. Paula Carroto, "Entrevista a Jacques Rancière", Público, I de enero de 20I2, en www.publico.es/culturas/416926/hablar-de-crisis-de-la-sociedad-es-culpar-a-sus-victimas, consultado el 30 de julio de 2018. 
Evidentemente, la relación entre estas posiciones diferentes es lejos de ser obvia y permanente; más bien es el resultado de construcciones políticas complejas que son basadas en la totalidad de las relaciones sociales. [...] No hay posición de sujeto cuyos vínculos con los otros estén permanentemente asegurados; y por consecuencia no hay identidad social adquirida que no sea sujeta a la acción de prácticas articulatorias. ${ }^{60}$

Aun así, es necesario analizar la construcción de resistencias de este tipo en todo el mundo capaces de ejercer presión sobre los gobiernos, que ayuden a crear una conciencia global, solidaria y colectiva. Cabría preguntarse cómo pueden producirse los cambios demandados por una sociedad que, a todas luces, no se ve representada por sus políticos, ni ve cubiertas sus necesidades colectivas en un momento en que el sistema del bienestar se tambalea. También el carácter institucional de estas luchas y, si es posible, ensayar otros modelos institucionales que puedan darles cabida. El debate está abierto, el germen del inconformismo y las ganas de cambiar las cosas están en la calle, en la sociedad y éste es, sin duda, un punto de partida necesario para el cambio de rumbo de los acontecimientos.

Algunos artistas han decidido reflexionar y crear imágenes en torno a estos movimientos colectivos en los que aparece siempre el símbolo de las fuerzas represoras como prolongación de las redes de poder político y económico. "Por lo común se acepta que todo arte es ideológico y que todo arte es usado políticamente, consciente o inconscientemente. Nos hallamos en una zona no neutral", ${ }^{61}$ Carlos Salazar en Manifestante (2007) ${ }^{62}$ representa esas protestas a escala mundial, inspiradas en imágenes de televisión de sucesos de Bogotá, Caracas, Madrid y París. La factura pictórica de la obra se pone de manifiesto en la textura de las pinceladas y aunque evidencia su origen mediático, cuenta con una estructura monocroma que trata de crear una escena atemporal con reminiscencias de un pasado cercano, en el que se focalice el motivo, la reivindicación social y la fuerza represora de los cuerpos de seguridad.

6o. Ernesto Laclau, "New Social Movements and the Plurality of the Social”, en D. Staler, New Social Movements and the State in Latin America (Ámsterdam: CEDLA), 33.

6I. Lucy R. Lippard, "Art and Ideology", en Catálogo de la exposición (Nueva York: New Museum of Contemporary Art, 1984).

62. Esta obra formó parte de la exposición "El fin de la historia y el retorno de la pintura" en el DA2 (Domus Artium, Salamanca) (junio-noviembre de 20II), para mayor información puede consultarse Paco Barragán (comisario), El fin de la historia... y el retorno de la pintura de historia" (Salamanca, DA2, 20II). 
$\mathrm{Du}$ Zhenjun crea unas imágenes con reminiscencias futuristas, la globalización llevada a sus últimas consecuencias. En la serie Super Towers (2010) ${ }^{63}$ aparece como elemento principal una edificación central que impone un punto de vista, una torre de Babel de arquitectura imposible. Ésta actúa como metáfora de la actual falta de entendimiento entre los distintos estamentos de la sociedad, de la incapacidad de que la clase política responda a las necesidades sociales. Se trata de unas imágenes en las que se intuyen acontecimientos del presente y de un pasado cercano, pero cuya proyección nos lleva hacia el futuro, un futuro caótico y apocalíptico, en el que la sociedad civil también toma la calle, ciudadanos empequeñecidos que generan multitudes con pancartas y que representan la fuerza de un necesario contrapoder. Técnicamente, son imágenes generadas por computadora, fotocollages que mantienen unas características inherentes al medio pictórico, hibridadas con referentes cinematográficos — se puede encontrar la influencia directa de las imágenes de Metrópolis (Fritz Lang, 1927).

Cabe preguntarse cuál es la capacidad del arte para dar respuesta a esta necesidad de cambio, de transformación. Ese campo de batalla que está en la calle, en el que miles de personas tratan por medios pacíficos de cambiar las cosas, también puede ser intervenido desde lo artístico. "Pone de manifiesto una incertidumbre fundamental sobre la configuración misma del territorio del conflicto, sobre lo que es la política y sobre lo que hace el arte". ${ }^{64}$

Aunque no es el objeto directo de esta investigación, sería necesaria una reflexión paralela que analizara los aspectos más importantes del arte político y del arte activista contemporáneo. Se considera necesario añadir cómo el arte crítico, el arte de resonancias políticas, es difícilmente recluido en el cubo blanco, cómo la fuerza de este tipo de manifestaciones se ve mermada en el momento en el que se institucionaliza. El espacio privilegiado del arte político debe ser, sin duda, el espacio público donde entra en contacto con los movimientos colectivos sociales y a los que se pueden añadir vías de significación alternativas, menos desgastadas que algunas de las expuestas hasta el momento. La creatividad puesta al servicio de reivindicaciones de carácter colectivo

63. Véase imágenes de esta serie de fotografía, así como mayor información relativa a la misma en https://kadist.org/work/the-tower-of-babel-independence-of-thecountry/, consultado el 25 de junio de 20I9. Para ver más fotografías de la serie consúltese http://www.faithistorment. $\mathrm{com} / 2016 / 03 /$ the-tower-of-babel-by-du-zhenjun.html, revisado el 25 de junio de 2019.

64. Jacques Rancière, "Estética y política: las paradojas del arte político", https://webs.ucm. es/info/artepltk/texto_ranciere.html, consultado el 30 de julio de 2018. 
I90

RUT MARTÍN HERNÁNDEZ

debe ser capaz de lanzar preguntas que cuestionen lo normativo, lo mediático, lo predecible y, de esta forma, encontrar vías de actuación múltiples, capaces de incidir en la complejidad de estas transformaciones, siempre polifacéticas, de despertar en la masa dormida una conciencia crítica y la necesidad de tener una actitud activa, reivindicativa, que luche por sus derechos. "Quizás el artista pueda producir algo que no sea simplemente una contestación, un análisis o una sesuda deconstrucción. Quizá el arte sea capaz de producir espacio público y, por lo tanto, político". ${ }^{65}$

En este sentido es necesaria una lectura de las imágenes que no focalice su carácter estético. Los paradigmas han cambiado y tendrían que ver con la idea de Benjamin: una innovación artística vinculada a una revolución social, en la que el artista interviene en los medios de producción y en el sistema. ${ }^{66}$ "El arte se transformó en un signo social estrechamente ligado a otros signos en una estructura de sistemas productores de valor, poder y prestigio".${ }^{67}$ En este sentido las aportaciones del arte a una conciencia social crítica basan su acierto en constituirse como punto de partida para la manipulación de signos artísticos que repercutan en un espectador que se convierte, a su vez, en lector activo de mensajes. Tal y como apunta Rancière, "un arte crítico tiene menos de un arte que revela las formas del poder que de un arte que modifica las líneas divisorias existentes entre los regímenes de representación sensibles". ${ }^{68}$

\section{Conclusiones}

Con base en lo expuesto se han considerado una serie de categorías de análisis (fig. 4) que permitan discutir los resultados obtenidos. Dichas categorías son las siguientes: I) la creación de imaginarios otros a partir del quiebre de los imaginarios colectivos sobre el tema de estudio; 2) imágenes abiertas a la subjetividad que posibiliten una entrada a lo sensible capaz de activar un pensamiento crítico y emancipador; 3) la visibilización de los modos en los que las redes

65. Yayo Aznar, "Arte, política y activismo", en http://webs.ucm.es/info/artepltk/textos/texto_aznar_inigo.html, consultado el 30 de julio de 2018.

66. Walter Benjamin, La obra de arte en la época de la reproductibilidad técnica (Ciudad de México: Itaca, 2003).

67. Ana María Guasch, El arte del siglo xx. Del posminimalismo a lo multicultural (Madrid: Alianza, 2000), 476 .

68. Rancière, "Estética y política: las paradojas del arte político". 


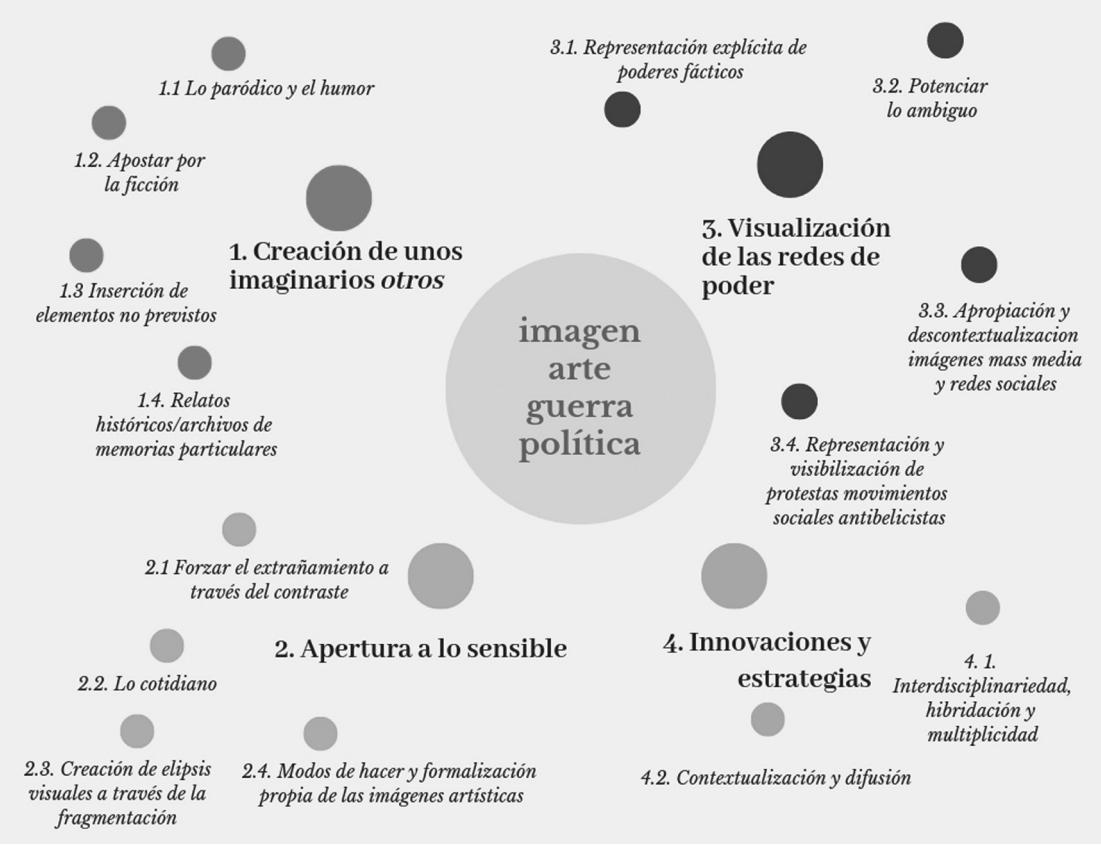

Fig. 4 Mapa visual de categorías de análisis.

de poder atraviesan los relatos históricos en torno a conflictos bélicos, y 4) las innovaciones y estrategias significativas detectadas en las obras analizadas y sus conexiones con los modos de hacer de las prácticas artísticas contemporáneas.

Con relación a la creación de unos imaginarios otros cabe señalar que la mayoría de las obras analizadas proponen unas formas de representación icónicas que tratan de cuestionar las imágenes de los conflictos bélicos de los medios de comunicación, y redes sociales, que han forzado unos imaginarios colectivos en los que la imagen de guerra bebe, a menudo, de las lógicas de la fotografía documental y de las imágenes de carácter propagandístico. Los modos en los que se separan de dichas lógicas se centran en: i) utilización de lo paródico y el humor como elemento desarticulador; 2) la creación de ficciones que son explícitas en las imágenes fotográficas que ponen en entredicho la veracidad del medio; 3) la inserción de elementos no previstos que detonan otros significados y configuran otros relatos de los acontecimientos mostrados. Dichos elementos a menudo son elementos cotidianos que aluden a acontecimientos no relevantes del conflicto, y 4) la utilización de las historias particulares 
con la finalidad de ofrecer una historia múltiple, plural y no lineal que quiebre el relato histórico tradicional, en el que los grandes acontecimientos funcionan como ejes articuladores del mismo.

Se considera que la capacidad de agencia de estas imágenes artísticas activa un pensamiento crítico y emancipador. En este sentido, es clave la creacción de imágenes abiertas a la subjetividad del espectador que permiten una entrada a lo sensible capaz de interpelar y forzar un posicionamiento crítico y, en consecuencia, político por medio del cual resignificar dichos conflictos. Dicho carácter abierto puede observarse en las obras analizadas a partir de las siguientes cuestiones: I) el extrańamiento que surge del contraste entre los elementos que conforman las representaciones, dicho contraste surge, en la mayor parte de las ocasiones, por la composición en una misma imagen de elementos de significados antagónicos, heterogéneos o claramente diferenciados; 2) introducción en las imágenes de elementos cotidianos fácilmente reconocibles por el espectador que permiten una identificación que posibilita ponerse en el lugar del otro y dejarse afectar por las situaciones sociopolítcas representadas en las imágenes; 3 ) creando elipsis visuales que formalmente vienen determinadas por la fragmentación de las imágenes, la producción de polípticos y series y la presentación de las mismas en el espacio a modo de instalación, y 4) por medio de cuidadas composiciones y una belleza formal propia de las imágenes del arte, que sirven como punto de partida para forzar una sensibilización en el espectador y buscar en la imagen otra serie de significados más allá de lo representado, cuestión que viene dada, asimismo, por un modo de mirar las imágenes artísticas en contraposición con las imágenes de los medios cuya contemplación, a menudo, está ligada a lo instantáneo. Podría decirse que estas imágenes resuenan en la mente del espectador y se fijan de una manera específica permitiendo una reflexión que se mantiene reververando en el tiempo.

Otra de las cuestiones destacables de las imágenes artísticas que reflexionan sobre los conflictos bélicos es mostrar y hacer visibles las redes de poder que configuran los relatos históricos. Esta estrategia se sirve de: I) representar explícitamente figuras políticas y conflictos determinados fácilmente identificables, que permiten hacer asociaciones en este sentido; por otra parte 2) genera un espacio icónico donde los elementos representados juegan a lo ambiguo y propician asociaciones no previstas en la imagen. Es, precisamente, en esta ambigüedad, donde el espectador establece conexiones específicas. Es significativo, asimismo, cómo en ocasiones, 3) se apropian de imágenes de 
los medios de comunicación y redes sociales y las presentan en las obras junto con otros elementos capaces de resignificarlas y desvelar los códigos mediante los cuales han sido producidas. Resulta, también significativa, la presencia de obras que, 4) visibilizan las protestas de los movimientos sociales en contra de conflictos bélicos concretos y muestran las consecuencias de la globalización. Estas obras utilizan los recursos icónicos de la pintura de historia para legitimizar y dar valor a estos otros acontecimientos que son traídos a primer plano del conflicto.

Cabría señalar que las obras analizadas utilizan estrategias que están en consonancia con los discursos propios del arte contemporáneo, en la medida en que su relación formal con la imagen, los procesos que despliegan y las estrategias que utilizan están siendo ensayados, también, en otros ámbitos de investigación desde las artes. Esta cuestión es significativa porque permite establecer una cartografía de las imágenes artísticas que se están produciendo en los últimos años con relación a las prácticas artísticas en el presente, tratando de innovar respecto a un tema que ha sido recurrente en el arte desde hace siglos. Esto pone en valor la capacidad de lo artístico para reflexionar de manera activa sobre conflictos específicos y para activar conciencias críticas capaces de generar espacio político. En este momento tenemos a nuestra disposición miles de imágenes sobre un acontecimiento en tiempo simultáneo al mismo pero, a pesar de su multiplicidad, dichas imágenes a menudo son muy parecidas, cabe entonces apreciar el esfuerzo de romper dichas retóricas visuales clónicas para ofrecer una mirada múltiple y compleja, que se considera, puede encontrarse en las obras analizadas.

Es pertinente plantear, a tenor de lo expuesto, una cuestión relevante para la capacidad de emancipación de estas prácticas y que se relaciona, directamente, con los ámbitos de contextualización y difusión de las mismas. En este sentido se entiende que, si tanto la producción de estas imágenes, como su exposición, no superan el ámbito institucional o de mercado del arte, dicha capacidad se verá mermada por el perfil del espectador que tiene contacto con las mismas. Establecer una mirada crítica al contexto de inserción de estas imágenes es clave para fomentar la construcción de los citados imaginarios otros, que únicamente pueden tener relevancia e impacto si son pensados, imaginados y construidos en el seno de lo social, entendiendo lo social como un ámbito capaz de acoger una miríada de subjetividades. Sería interesante plantear esta investigación como un punto de partida para otras aproximaciones a la imagen bélica desde el estudio específico de un contex- 
to concreto que ponga en relevancia las particularidades de los acercamientos artísticos a lo local y desde lo particular del espacio político y social objeto de estudio. Dicho acercamiento debería incluir de forma explícita un avance hacia la contextualización de dichas imágenes y las consecuencias que esto tiene en el significado de las mismas. \&

N.B. Esta investigación se ha llevado a cabo en el marco del proyecto de investigación: "Imágenes, acción y poder. Agencia icónica y prácticas de la imagen contemporánea (FF2017-84944-P). Mineco (I+D excelencia). 